\title{
Pengaruh Penambahan Emulsifier dan Stabilizer Terhadap Kualitas Santan Kelapa
}

\author{
Suci L. Sidika ${ }^{*}$, Feti Fatimaha, Meiske S. Sangia \\ aJurusan Kimia, FMIPA, Unsrat, Manado
}

K A T A K U N I

Santan kelapa

Emulsifier

Stabilizer

\begin{tabular}{l}
\hline K E Y W O R D S \\
\hline Coconut milk \\
Emulsifier \\
Stabilizer
\end{tabular}

AVAILABLE ONLINE

18 Juni 2013

\begin{abstract}
A B S T R A K
Santan merupakan emulsi minyak dalam air yang diperoleh dengan cara memeras daging buah kelapa segar yang telah dihaluskan. Beberapa penelitian telah dilakukan untuk meningkatkan waktu penyimpanan santan. Beberapa teknik yang digunakan adalah asteurisasi, variasi kecepatan putar maupun pengaruh suhu dingin untuk menambah waktu simpan santan. Penelitian ini bertujuan untuk menentukan pengaruh penambahan emulsifier dan stabilizer terhadap kualitas santan kelapa. Kualitas yang diukur yaitu stabilitas emulsi pada berbagai perbandingan kelapa parut:air, jenis emulsifier serta konsentrasi stabilizer. Hasil yang diperoleh menunjukkan bahwa krim santan yang diperoleh dari ekstraksi kelapa parut:air dengan perbandingan 4:1 memiliki stabilitas emulsi terbaik hingga jam ke-10. Pemakaian emulsifier sintetik polyoxyethylene (20) sorbitan monostearat dengan konsentrasi 1.00\% dan stabilizer guar gum dengan konsentrasi $0.75 \%$ dapat meningkatkan stabilitas emulsi hingga mencapai $100 \%$ pada pengamatan sampai hari ke-13.

A B S T R A C T

Coconut milk is an oil-in-water emulsion obtained by squeezing fresh coconut meat. Several studies have been done to improve coconut milk storage time. Several techniques used to increase storage time of coconut milk are pasteurization, rotational speed variation and the use of low temperature. This study was aimed to determine the effect of emulsifier and stabilizer to the quality of coconut milk. Quality measured was the stability of emulsion at several ratio of cocout to water, type of emuslifier, and stabilizer concentration. The result revealed that coconut milk cream obtained from the extraction of coconut:water ratio of $4: 1$ has the best emulsion stability up to 10 hours. The use of $1.00 \%$ synthetic emulsifier polyoxyethylene (20) sorbitan monostearate and $0.75 \%$ stabilizer guar gum increased the stability of the emulsion up to $100 \%$ at day 13.
\end{abstract}

\section{Pendahuluan \\ Indonesia merupakan salah satu negara tropis penghasil tanaman kelapa (Cocos nucifera L.) yang mempunyai manfaat besar dalam kehidupan manusia sehari-hari mulai dari akar, batang sampai ke pucuk. Tanaman kelapa juga memberi devisa besar bagi perekonomian rakyat dan negara. Salah satu bagian yang bermanfaat adalah buah kelapa yang dapat diolah menjadi berbagai jenis makanan atau minuman. Daging buahnya dapat diolah}

menjadi santan maupun minyak kelapa sedangkan tempurungnya dapat dijadikan bahan untuk arang aktif.

Santan merupakan emulsi minyak dalam air yang diperoleh dengan cara memeras daging buah kelapa segar yang telah dihaluskan. Kebutuhan masyarakat terhadap produk santan diimbangi dengan tingginya proses pembusukan santan. Hal ini disebabkan santan mempunyai kandungan air, lemak dan protein yang cukup tinggi. Oleh karena itu, sangat diperlukan suatu teknik pengawetan

*Corresponding author: Jurusan Kimia FMIPA UNSRAT, Jl. Kampus Unsrat, Manado, Indonesia 95115; Email address: cysuchy@ymail.com

Published by FMIPA UNSRAT (2013) 
santan. Dari penelitian sebelumnya yang dilakukan Prihatini (2008), telah dilakukan teknik pasteurisasi santan kelapa untuk meningkatkan waktu penyimpanan santan sedangkan teknik pembekuan santan kelapa seperti telah dilakukan Raharja dan Dwiyuni (2008). Pada penelitian tersebut, tidak dilakukan penambahan emulsifier maupun stabilizer. Emulsifier dan stabilizer dalam hal ini dapat meningkatkan stabilitas emulsi santan sehingga santan bisa lebih tahan lama.

Menurut McClements dalam Fatimah (2005), emulsifier merupakan molekul yang mengabsorbsi pada permukaan droplet yang baru terbentuk selama homogenisasi dan membentuk membran protektif yang menjaga droplet agar tidak terjadi agregasi. Stabilizer dalam hal ini ditambahkan untuk menambah viskositas fase kontinyu emulsi sehingga meningkatkan stabilitas emulsi dengan mencegah pergerakan droplet emulsi. Penelitian ini dilakukan karena belum adanya penelitian tentang penambahan emulsifier dan stabilizer dalam produk emulsi santan serta pengaruh teknik pasteurisasi dan pembekuan pada emulsi santan terhadap kualitas santan tersebut.

\section{Metode}

Penelitian dilakukan dalam tiga tahapan utama yaitu, (1) ekstraksi santan, (2) penentuan jenis emulsifier dan (3) penentuan konsentrasi stabilizer.

\subsection{Ekstraksi Santan}

Daging buah kelapa diekstraksi dengan air untuk mendapatkan santan pada perbandingan kelapa:air 2:1, 3:1 dan 4:1. Hasil ekstraksi dari santan biasa serta krim santan (santan yang didiamkan selama \pm 5-6 jam) diuji stabilitas emulsi santan maupun krim dari jam ke-0 sampai jam ke10.

\subsection{Penentuan Jenis Emulsifier}

Santan dan krim yang dibuat dengan perbandingan kelapa parut:air dengan stabilitas emulsi terbaik selanjutnya diperlakukan dengan penambahan dua jenis emulsifier sintetik yaitu polyoxyethylene (20) sorbitan monostearate (PSMS) dan polyoxyethylene (20) sorbitan monooleate (PSMO). Dilakukan pengujian stabilitas emulsi dari hari ke-0 sampai hari ke-13.

\subsection{Penentuan Konsentrasi Stabilizer}

Santan dan krim yang dibuat dengan perbandingan kelapa parut-air dengan stabilitas emulsi terbaik selanjutnya dilakukan penambahan stabilizer guar gum dengan variasi konsentrasi 0.50\%, 0.75\% dan 1.00\%. Dilakukan pengujian stabilitas emulsi dari hari ke-0 sampai hari ke-13. Stabilitas emulsi adalah tinggi lapisan atas (krim santan) dibagi dengan tinggi santan.

Stabilitas emulsi (\%)

$$
=\frac{\text { tinggi krim santan yang terpisah }}{\text { tinggi total santan }} \times 100 \%
$$

\section{Hasil dan Pembahasan}

\subsection{Ekstraksi Santan}

Volume krim santan yang diperoleh dari ekstraksi kelapa parut:air 4:1 lebih banyak dibandingkan dengan ekstraksi kelapa parut:air 3:1 dan 2:1. Data hasil pengujian nilai stabilitas emulsi dari krim santan dengan perbandingan kelapa parut:air (2:1, 3:1 dan 4:1) dapat dilihat pada Gambar 1 dan 2.

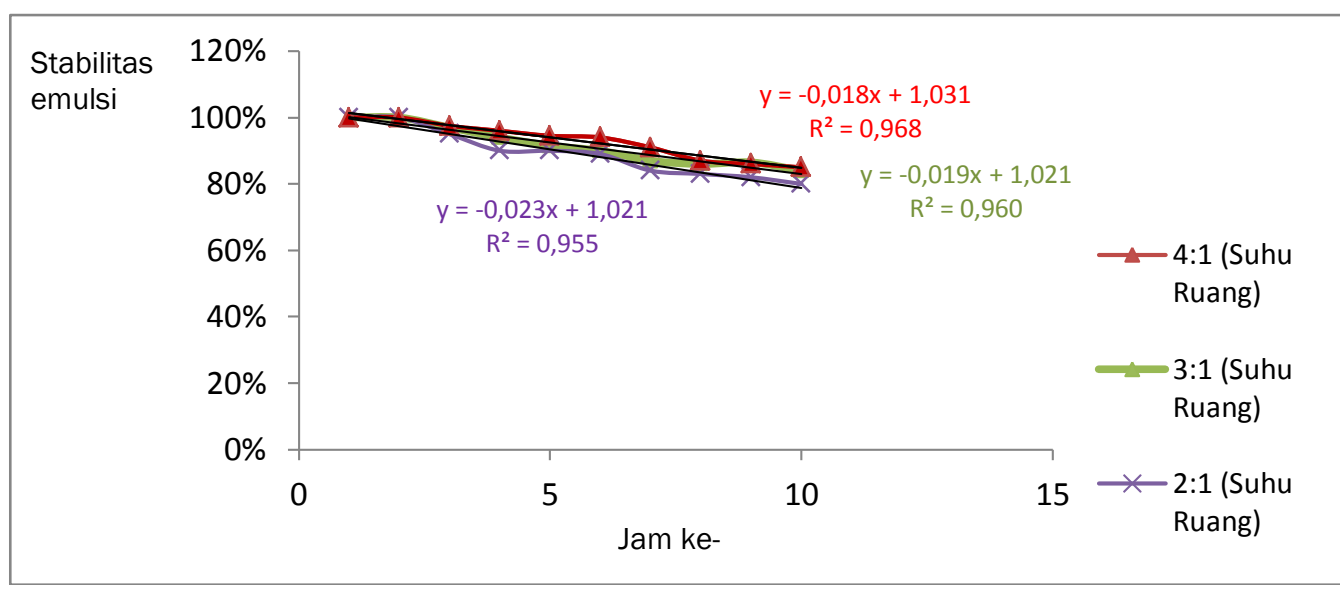

Gambar 1 - Stabilitas emulsi krim santan pada berbagai perbandingan kelapa parut:air pada suhu ruang 


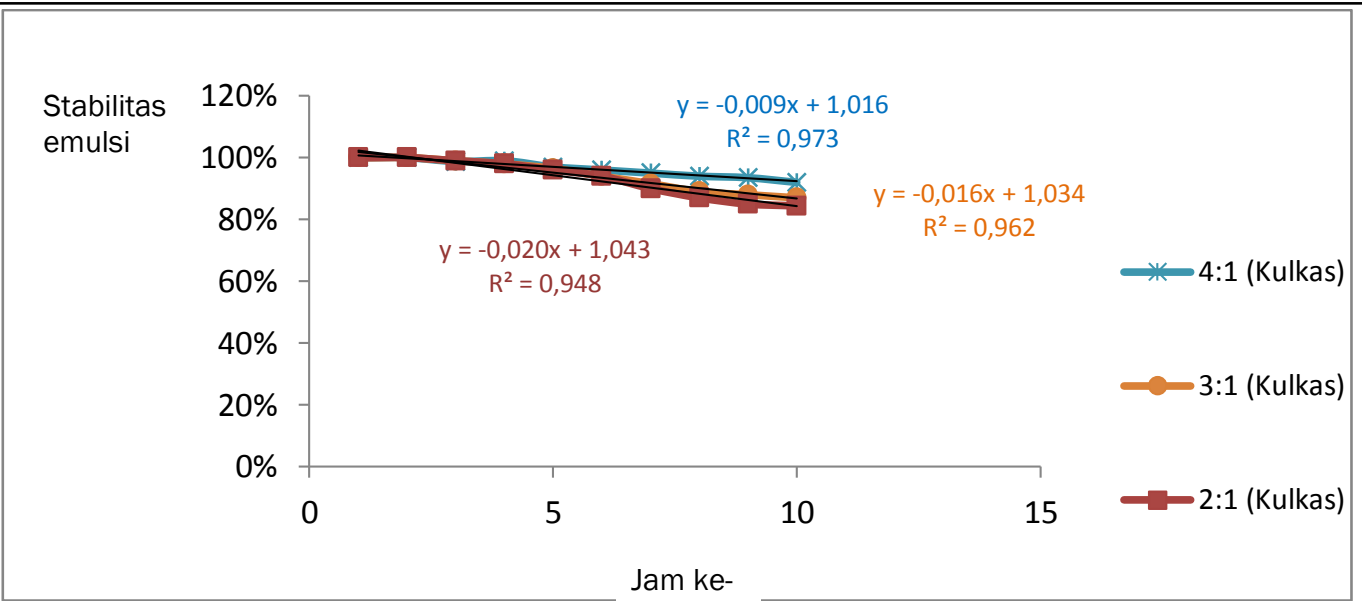

Gambar 2 - Stabilitas emulsi krim santan pada berbagai perbandingan kelapa parut:air pada suhu kulkas

Dari data tersebut diketahui bahwa nilai stabilitas emulsi dari krim santan hasil ekstraksi kelapa parut:air dengan perbandingan 4:1 memiliki nilai stabilitas emulsi terbaik (slope terkecil) sebesar -0.018 pada suhu ruang dan -0.009 pada suhu kulkas. Krim santan dengan perbandingan 3:1 memiliki nilai stabilitas emulsi sebesar -0.019 untuk suhu ruang dan -0.016 untuk suhu kulkas, sedangkan untuk perbandingan 2:1 memiliki nilai 0.023 dan -0.020 untuk suhu ruang dan kulkas.

Pengujian stabilitas emulsi ini dilakukan tanpa penambahan emulsifier dan stabilizer terhadap santan kelapa, hal ini bisa menyebabkan santan cepat rusak, sehingga pengukuran stabilitas emulsi dilakukan dari jam ke-1 sampai jam ke-10. Menurut Agustina dalam Nawansih et al. (2011), santan mengandung air, protein, dan lemak cukup tinggi sehingga mudah ditumbuhi oleh mikroba pembusuk sehingga menyebabkan krim santan mudah rusak (daya simpan kurang dari 24 jam). Kerusakan tersebut antara lain pecahnya emulsi santan, timbulnya aroma tengik, dan perubahan warna menjadi lebih gelap atau agak coklat.
Dapat dilihat juga bahwa adanya perbedaan antara santan yang disimpan dalam suhu ruang dan santan yang disimpan dalam kulkas, santan yang disimpan dalam kulkas memiliki nilai stabilitas emulsi yang lebih baik, hal ini mungkin disebabkan karena suhu dingin mencegah bakteri untuk berkembang biak lebih cepat. Bakteri atau jamur dapat menyebabkan santan menjadi cepat rusak.

Berdasarkan hasil penelitian tersebut, diketahui bahwa ekstraksi santan dengan perbandingan kelapa parut:air 4:1 memiliki nilai slope terendah, sehingga perbandingan kelapa parut:air 4:1 yang dipilih untuk digunakan dalam tahapan penambahan emulsifier dan stabilizer selanjutnya.

\subsection{Pemilihan Jenis Emulsifier}

Berdasarkan uji stabilitas emulsi maka krim santan yang diperoleh dari perbandingan kelapa parut:air 4:1 memiliki stabilitas emulsi terbaik. Penambahan emulsifier dan stabilizer dimaksudkan untuk meningkatkan stabilitas emulsi santan. Hasil uji stabilitas emulsi krim santan dengan penambahan emulsifier dan stabilizer disajikan pada Gambar 3.

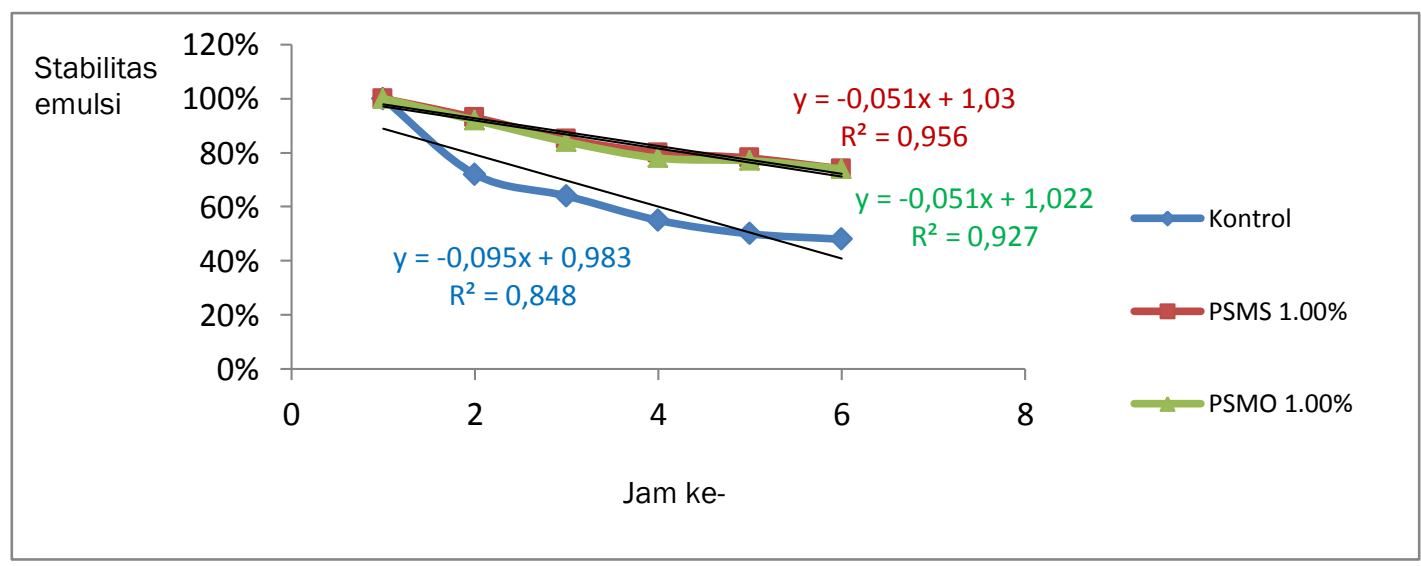

Gambar 3 - Stabilitas emulsi krim santan pada penambahan dua jenis emsifier 
Berdasarkan Gambar 3 diketahui bahwa stabilitas emulsi dari krim santan kelapa yang ditambahkan emulsifier PSMS memiliki nilai sebesar -0.051, sama dengan stabilitas emulsi krim santan yang ditambahkan emulsifier PSMO sebesar -0.051 dan terakhir kontrol sebesar -0.095. Proses pengamatan stabilitas emulsi terhenti pada hari kelima, dikarenakan setelah itu santan yang dibiarkan menjadi rusak/berjamur. Hal itu mungkin dikarenakan adanya kontaminasi yang terjadi dengan bakteri. Sumber kontaminasi ini bisa berasal dari bahan baku kelapa, peralatan yang digunakan selama proses ekstraksi dan pengolahan

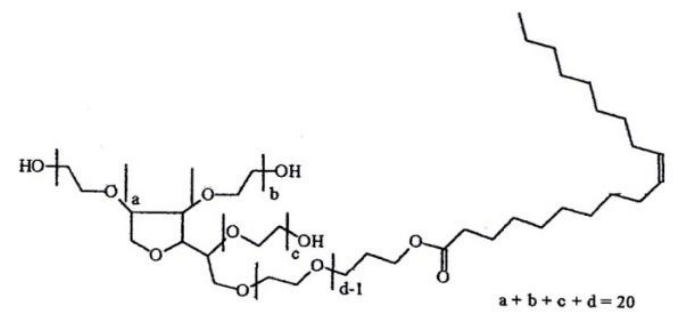

(a) maupun kondisi lingkungan kerja. Kelapa yang diperoleh dari pasar bisa saja telah terkontaminasi oleh bakteri/mikroorganisme yang lebih mudah mencemari kelapa dikarenakan tidak adanya pelindung berupa tempurung atau sabut kelapa.

Emulsifier yang digunakan dalam penelitian ini adalah emulsifer sintetik (buatan) yaitu polyoxyethylene (20) sorbitan monostearate (PSMS) dan polyoxyethylene (20) sorbitan monooleat (PSMO). PSMS memiliki nilai HLB (HidrophilicLipophilic Balance) 14.9. Sedangkan PSMO memiliki nilai HLB 15. Rumus molekul dari emulsifier sintetik PSMS dan PSMO dapat dilihat pada Gambar 4.

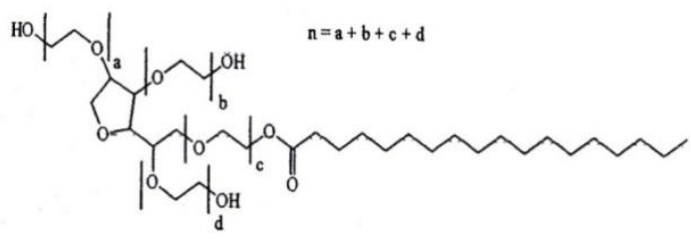

(b)

Gambar 4 - (a) Polyoxyethylene (20) sorbitan monostearate, (b) Polyoxyethylene (20) sorbitan monooleat (Zapsalis, 1986)

\subsection{Pemilihan Konsentrasi Stabilizer}

Berdasarkan uji stabilitas emulsi maka krim santan yang diperoleh dari perbandingan kelapa parut:air 4:1 memiliki stabilitas emulsi terbaik. Penambah Volume krim santan yang diperoleh dari ekstraksi kelapa parut:air 4:1 lebih banyak dibandingkan den

Tahapan selanjutnya adalah pemilihan konsentrasi stabilizer terbaik dengan konsentrasi 0.50\%, 0.75\% dan 1.00\% (Gambar 5). Stabilizer adalah bahan tambahan makanan yang membantu mempertahankan struktur dari makanan tersebut.
Stabilizer membantu terjadinya pemisahan minyak atau air dari produk emulsi. Dari hasil pengujian stabilitas emulsi dengan penambahan stabilizer di atas, diketahui bahwa semakin besar konsentrasi stabilizer maka emulsi tersebut akan semakin kental. Penambahan stabilizer dengan konsentrasi 0.75\% dan $1.00 \%$ memiliki stabilitas emulsi yang sama besar, sedangkan penambahan stabilizer dengan konsentrasi $0.50 \%$ memiliki nilai cukup rendah karena kestabilannya terganggu pada pengukuran hari ke-6.

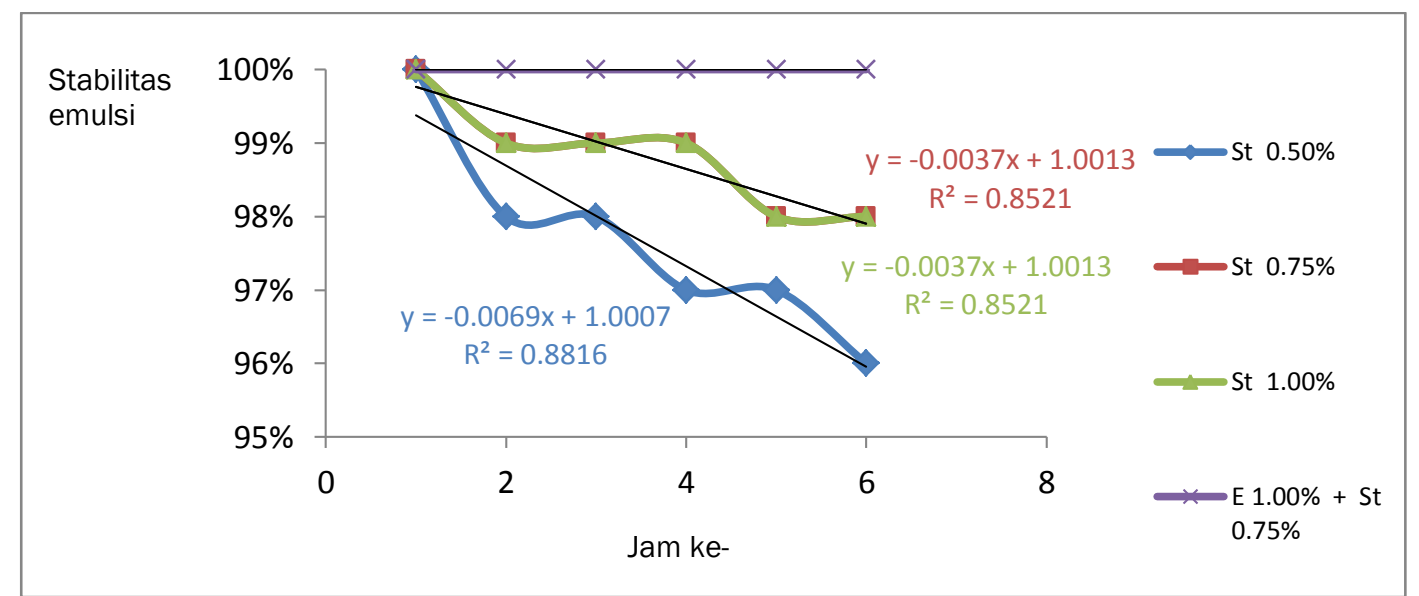

Gambar 5 - Stabilitas emulsi krim santan pada variasi penambahan konsentrasi stabilizer dan kombinasi stabilizer $0.75 \%$ - emulsifier $1.00 \%$ 
Berdasarkan nilai slope yang sama antara stabilizer dengan konsentrasi $0.75 \%$ dan $1.00 \%$, maka untuk pengujian tahap selanjutnya dipakai stabilizer dengan konsentrasi $0.75 \%$. Stabilizer $0.75 \%$ dipilih karena dari segi kekentalan cukup, sedangkan untuk stabilizer $1.00 \%$ sangat kental. Dari hasil pengujian yang dilakukan, variasi penambahan emulsifier PSMS 1.00\% dan stabilizer $0.75 \%$ menghasilkan nilai slope terendah. Stabilitas emulsi krim santan tersebut bertahan 100\% tanpa terjadi pemisahan (Gambar 5).

Stabilizer yang digunakan dalam penelitian ini adalah stabilizer guar gum. Guar gum dikenal sebagai bahan pengental alami yang sering digunakan dalam pembuatan puding atau es krim. Struktur kimia dari guar gum dapat dilihat pada Gambar 6.

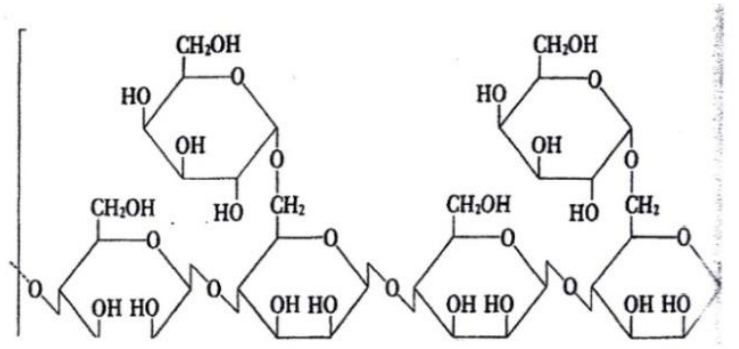

Gambar 6 - Struktur guar gum (Zapsalis, 1986)

\section{Kesimpulan}

Krim santan dengan perbandingan kelapa parut-air 4:1 memiliki stabilitas emulsi yang lebih baik daripada santan kelapa (tanpa pemisahan krim). Penambahan emulsifier Polyoxyethylen (20) sorbitan monostearat dengan konsentrasi $1.00 \%$ dan stabilizer guar gum dengan konsentrasi $0.75 \%$ dapat meningkatkan stabilitas emulsi hingga 100\% sampai pengamatan pada hari ke-13.

\section{Daftar Pustaka}

Association of Official Analytical Chemist (AOAC) 925.45. 1999. Official Methods of Analysis of The Association of Official Analytical Chemist. 15th Edition. USA : Kenneth Helrich. Chapter 44.1.03.

Fatimah, F. 2005. Efektivitas Antioksidan dalam Sistem Oil-in-Water. [Disertasi]. Sekolah Pasca Sarjana IPB. Bogor.

Nawansih, O., M. Erna, N. K. Rianto. 2011. Kajian Pengawetan Krim Santan Kelapa Menggunakan Natrium Bisulfit.Prosiding Seminar Nasional Sains dan Teknologi - IV. Bandar Lampung, 2930 November 2011.

Prihatini, R. I. 2008. Analisa Kecukupan Panas Pada Proses Pasteurisasi Santan. [Skripsi]. Institut Pertanian Bogor. Bogor.

Raharja, S. dan M. Dwiyuni. 2008. Kajian Sifat Fisiko Kimia Ekstrak Minyak Kelapa Murni (Virgin Coconut Oil, VCO) Yang Dibuat Dengan Metode Pembekuan Krim Santan.Jurnal Teknik Industri Pertambangan. 18 (2) : 71 - 78.

SNI-01-2891-1992. 1992. Cara Uji Makanan dan Minuman. Dewan Standar Nasional Indonesia. Jakarta.

Zapsalis, C., and A. Beck. 1986. Food Chemistry and Nutritional Biochemistry. Penerbit Macmilan Publishing Company. New York. 